\title{
A Rare Case: Herpes Simplex Encephalitis
}

\author{
Nadir Bir Olgu: Herpes Simpleks Ensefaliti
}

\begin{abstract}
(D) Cansu Kiziltas' ${ }^{1}$ (D) Vildan Ozer², (D) Selman Yeniocak ${ }^{3}$, ID Abdulkadir Gunduz ${ }^{1}$
1- Karadeniz Technical University Faculty of Medicine Department of Emergency Medicine, Trabzon-Turkey. 2- Rize State Hospital, Department of Emergency Medicine, Rize-Turkey. 3- Haseki Training Research Hospital, Department of Emergency Medicine, Istanbul-Turkey.
\end{abstract}

\begin{abstract}
Herpes Simplex Encephalitis (HSE) is one of the most common causes of sporadic encephalitis and has the most mortal progression. A 22-year-old female patient applied to the emergency department with nausea and vomiting that lasted three days. The patient Cerebrospinal Fluid (CSF) was clear, the glucose ratio was low, and the protein ratio was high in the Lumbar Puncture (LP). HSV-DNA tests were requested with CSF culture and Polymerase Chain Reaction (PCR). Based on the LP results, and considering viral encephalitis, acyclovir treatment was started. The patient died on the 5th day while her treatment was continuing. HSV-DNA with PCR in BOS is the gold standard for the diagnosis of HSE. The most effective agent in treatment is acyclovir. The prognosis of the disease is poor.

\section{ÖZET}

Herpes Simplex Ensefaliti (HSE), sporadik ensefalitin sık nedenlerinden birisi ve en ölümcül seyredenidir. 22 yaşında kadın hasta, son üç gündür olan bulantı ve kusma şikayeti ile acil servise başvurdu. Lomber Ponksiyonda (LP) hastanın Beyin Omurilik Sivısı (BOS) berrak görünümdeydi, glikoz oranı düşük ancak protein oranı yüksekti. BOS kültürü ve Polimeraz Zincir Reaksiyonu (PCR) ile HSV-DNA testleri istendi. LP sonuçları desteğinde viral ensefalit düşünülerek asiklovir tedavisi başlandı. Hasta 5. günde tedavisi devam ederken öldü. BOS'ta PCR ile HSV-DNA testi HSE teşhisi için altın standarttır. Tedavide en etkili ajan asiklovirdir. Hastalı̆̆ın prognozu kötüdür.
\end{abstract}

Keywords:

Encephalitis,

Herpes,

Vomiting.

Anahtar Kelimeler:

Ensefalit,

Herpes,

Kusma.

\section{INTRODUCTION}

Herpes Simplex Encephalitis (HSE) is one of the most common causes of sporadic encephalitis and has the most mortal progression. It appears with the retrograde spread of the primary infection or latent virus to brain parenchyma from peripheral neurons. Herpes Simplex Virus (HSV) Type1 is active in $95 \%$ of cases. The virus, which enters the body through oropharyngeal mucosa, conjunctiva, and damaged skin, remains latent in neurons and causes recurrent infections. Its annual prevalence was reported as 2-4/million. Although it can be seen in all ages and genders, it does not show seasonal variability $(1,2)$. In this article, the purpose was to discuss a patient who applied to the emergency department with nausea and vomiting complaints and was diagnosed with HSE accompanied by the literature.

\section{CASE}

A 22-year-old female patient applied to the emergency department with nausea and vomiting complaints that continued for 3 days. When the patient arrived, her general condition was moderate, conscious, and cooperative. The patient's Glasgow coma score was 15, arterial blood pressure was 110/70 $\mathrm{mmHg}$, pulse count was $100 / \mathrm{min}$, body temperature was $37.1^{\circ} \mathrm{C}$, and the respiratory count was $16 / \mathrm{min}$. In the neurological examination of the patient, who had no previous diseases in her history, the pupils were isochoric, and the light reflex was bilaterally positive. No loss of sense and strength were detected in the extremities of the patient who did not have stiffness in the neck. Other system examinations were normal. The patient was taken under observation, and intravenous (IV) hydration was started, and IV 10mg metoclopramide was administered. Her serum electrolyte levels were normal in blood tests, Creactive protein (CRP) was $4.8 \mathrm{mg} / \mathrm{L}$ (range $0-5$ ), leukocyte $8715 / \mathrm{mm}^{3}$ (range $3980-10200 / \mathrm{mm}^{3}$ ), platelet (plt) value 142 103/uL (range 142-424) and hemoglobin value was $12.7 \mathrm{~g} / \mathrm{dl}$ (range 14.1-18.1). No pathologies were detected in the computed tomography (CT) and magnetic resonance imaging (MRI). In her clinical follow-ups, the patient had agitation and tonic-colonic contractions in lower and upper extremities. Seizure control was ensured by administering IV $5 \mathrm{mg}$ midazolam, and IV 750mg levetiracetam loading dose. The cerebrospinal fluid (CSF) was clear, glucose ratio was low and protein content was high in lumbar puncture (LP). Samples were taken and sent to the microbiology laboratory to be examined for HSV-DNA with both CSF culture and Polymerase Chain Reaction (PCR) methods. Based on the result of LP, viral encephalitis was suspected, and IV acyclovir $500 \mathrm{mg}$ was administered as the first dose. Despite the fluid infusion, when blood pressure began to drop, pulse accelerated and when she had anuria, inotrope support was initiated. Soon after, when consciousness deteriorated, she was intubated and transferred to the

\section{Received: 25.05 .2020}

Accepted: 02.09.2020

Correspondence: Cansu Kiziltas. Karadeniz Technical University Faculty of Medicine Department of Emergency Medicine Trabzon, Turkey. E-mail: dr.cansu.kiziltas@gmail.com

Cite this article as: Kiziltaş C, Ozer V, Yeniocak S, Gunduz A. A Rare Case: Herpes Simplex Encephalitis. Phnx Med J. 2020;2(3):168-170. 


\section{Kiziltas et al}

intensive care unit. HSV-1 and HSV-DNA positivity were detected as a result of the CSF culture of the patient during her time in the intensive care unit. While her treatment continued, the patient died on the fifth day.

\section{DISCUSSION}

HSV, with the only natural source being human, and widely found in the world, is transmitted to the body from oropharyngeal mucosa, conjunctiva, and damaged skin. Despite the development of antibodies after HSV infection, the virus remains in the latent phase in neurons causing that the person is a lifelong carrier. Although $90 \%$ of people have antibodies, it is not known how the virus activates and causes encephalitis. The entry of the virus into the Central Nervous System (CNS) is via the olfactory or trigeminal neural path with viremia (3).

Patients often apply to the hospital with nonspecific prodromal symptoms like rapid-progressing fever, headaches, and vomiting in HSE. Specific symptoms can be seen as behavioral disorders, epileptic seizures, focal neurological deficits, hemiplegia, speech disorders, amnesia, stupor, and coma (4). Our patient had applied to the emergency department with nonspecific complaints like nausea and vomiting. In the emergency department, she had behavioral changes including aggression, tonic-colonic contractions, in other words, grand mall epileptic seizure, and postseizure consciousness change.

To evaluate encephalitis, brain CT is not sensitive especially in the early stages of the disease. A total of $25-80 \%$ of patients have an increase in hypodense lesions, edema, or contrasting in the temporal lobe a few days after the onset of HSE, which is a distinguishing finding compared to other encephalitis cases (5). MRI of the brain is the most sensitive and specific imaging method especially at the onset of the disease and is superior to CT for diagnostic purposes. Asymmetric hyper intense lesions are detected in T2-weighted sequences in brain MRI, which corresponds to the edema areas in the insular cortex and mesotemporal and orbitofrontal lobes (6). Some researchers argued that, in the early stages of HSE, there is often diffusion limitation in diffusion-weighted imaging (DWI), which suggests that it may be among the earliest neuroradiological findings (7). No pathological findings were detected in the brain CT, MRI, and DWI of our patient.

All patients who have encephalitis should undergo LP unless they are contraindicated, but the empirical treatment should not be delayed. Detecting HSV-DNA and PCR in CSF is the gold standard for HSE diagnosis, and was determined to have $98 \%$ sensitivity and 94$100 \%$ specificity. Detecting HSV-DNA with PCR in CSF can be found to be positive 24 hours after the onset of the symptoms of the disease until one week after the treatment (8). After LP, the samples of our patient were sent to the microbiology laboratory for examination of HSV-DNA with both the CSF culture method and PCR method.

Seizures are frequent during the disease because of the inflammatory epileptogenic factor in HSE. One of the antiepileptic drugs like levetiracetam, lacosamide, valproate sodium are used with midazolam or propofol in HSE patients who have seizures (9). To our patient, who had a tonic-clonic seizure during examination in the emergency department, seizure control was performed by administering IV $5 \mathrm{mg}$ midazolam and IV 750mg levetiracetam loading dose, as reported in the literature.

The most effective agent in HSE treatment is acyclovir, which is used IV for 21 days at a dose of $30 \mathrm{mg} / \mathrm{kg} /$ day by dividing into 3 equal doses per day. In a previous study, the mortality rate was $50-55 \%$ in patients treated with vidarabine, and $20-30 \%$ in patients treated with acyclovir (10). As reported in the literature, IV $500 \mathrm{mg}$ acyclovir was given to our patient as the first dose. HSE prognosis is usually poor. The mortality rate is $70 \%$ in untreated cases; however, a $92 \%$ success rate can be achieved when early treatment is initiated. In addition to respiratory and circulatory failure, high intracranial pressure associated with seizures, brain edema, and herniation may develop among major acute neurological complications. The sequels that develop secondarily to HSE are irreversible $(5,11)$. Our patient died in the intensive care unit on the $5^{\text {th }}$ day of her treatment.

Conclusion: In patients who apply to the emergency department with nonspecific complaints like nausea and vomiting, etiological causes should be examined, and it should be kept in mind that there may be encephalitis. The diagnostic process should be accelerated and treatment must be started in the early period to reduce mortality rates.

Conflicts of Interest

The authors have no conflicts of interest to declare.

\section{REFERENCES}

1. Jørgensen LK, Dalgaard LS, Østergaard LJ, Norgaard M, Mogensen TH. Incidence and mortality of herpes simplex encephalitis in Denmark: a nationwide registry-based cohort study. J Infect. 2017;74(1):42-9.

2. Granerod J, Cousens S, Davies NW, Crowcroft NS, Thomas SL. New estimates of incidence of encephalitis in England. Emerg Infect Dis. 2013;19(9):1455-1462.

3. Jennische E, Eriksson CE, Lange S, Trybala E, Bergström T. The anterior commissure is a pathway for contralateral spread of herpes simplex virus type 1 after olfactory tract infection. J Neurovirol. 2015;21(2):129-47.

4. Riancho J, Delgado-Alvarado M, Sedano MJ, Polo JM, Berciano J. Herpes simplex encephalitis: clinical presentation, neurological sequelae and new prognostic factors. Ten years of experience. Neurol Sci. 2013;34:1879-81.

5. Bradshaw MJ, Venkatesan A. Herpes simplex Virus-1 encephalitis in adults: pathophysiology, diagnosis, and management. Neurotherapeutics. 2016;13(3):493-508. 
Phnx Med J. November, 2020. Volume 2 No 3

6. Misra UK, Kalita J, Phadke RV, Wadwekar V, Boruah DK, Srivastava A, et al. Usefulness of various MRI sequences in the diagnosis of viral encephalitis. Acta Trop. 2010;116:206-11.

7. Sawlani V. Diffusion-weighted imaging and apparent diffusion coefficient evaluation of herpes simplex encephalitis and Japanese encephalitis. J Neurol Sci. 2009;287:221-6.

8. Steiner I, Schmutzhard E, Sellner J, Chaudhuri A, Kennedy PGE. EFNS-ENS guidelines for the use of PCR technology for the diagnosis of infections of the nervous system. Eur J Neurol. 2012;19:1278-91.

9. Armangue T, Leypoldt F, Malaga I, Raspall-Chaure M, Marti I, Nichter C, et al. Herpes simplex virus encephalitis is a trigger of brain autoimmunity. Ann Neurol. 2014;75:317-323.

10. Solomon T, Michael BD, Smith PE, Sanderson F, Davies NWS, Hard IJ, et al. Management of suspected viral encephalitis in adultsAssociation of British Neurologists and British Infection Association National Guidelines. J Infect. 2012;64:347-73.

11. Steiner I, Benninger F. Update on herpes virus infections of the nervous system. Curr Neurol Neurosci Rep. 2013;13(12):414. 